\title{
Meta-analysis on Element of Cognitive Conflict Strategies with a Focus on Multimedia Learning Material Development
}

\author{
Radhiah Ab Rahim ${ }^{1}$, Norah Md Noor ${ }^{1} \&$ Norasykin Mohd Zaid ${ }^{1}$ \\ ${ }^{1}$ Faculty of Education, Universiti Teknologi Malaysia, Johor Bahru, Johor, Malaysia \\ Correspondence: Norah Md Noor, Faculty of Education, Universiti Teknologi Malaysia, Johor Bahru, Johor, \\ Malaysia. Tel: 607-553-4392. E-mail: norah@utm.my
}

\author{
Received: November 6, 2014 Accepted: March 16, 2015 Online Published: June 28, 2015 \\ doi:10.5539/ies.v8n13p73 URL: http://dx.doi.org/10.5539/ies.v8n13p73
}

\begin{abstract}
Multimedia materials are becoming more commonly used in curricula. Multimedia learning tools that integrate text, graphics, audio, video, and animation make learning more interesting and easier for understanding a concept. These tools have been used in different ways over the years to support student learning in all branches of education. Diverse teaching strategies have been adopted in developing multimedia learning materials in many interesting designs. These strategies are designed to achieve a number of objectives. One of them is to overcome misconception among the students. Theoretically, misconception is a point at which students have understood certain concepts in the wrong manner. Usually, those students who are in this situation refuse to switch to the right one. Cognitive conflicts strategy is a part of psychological theories of conceptual change. This strategy is effective in correcting a misconception as well as in improving performance. Once an unreliable event is mismatched with the preconception held by the student, cognitive conflict will take place. The student will engage with the learning material and reconstruct his or her concepts to overcome conflict. There has been a lot of researches related to cognitive conflict strategy in Science and Mathematics education. This strategy has been demonstrated to improve students' performance and misconception. Still, a lot of strategies have been implemented through face-to-face classroom instruction. With the growth of multimedia resources, a cognitive conflict strategy is believed to be employed when developing multimedia learning material. Even so, which elements of cognitive conflict strategy are usable within multimedia learning materials are still an ongoing inquiry. This research attempts to investigate elements of cognitive conflict strategy that could be embedded within multimedia learning materials that might effectively overcome the students' misconception based on detailed literature review using meta-analysis technique. After being analysed qualitatively, five elements of cognitive conflict strategy have been identified: (1) meaningful information; (2) challenging students' existing concept; (3) ability to gain attention, (4) motivation, and (5) comfortability in using the multimedia learning materials.
\end{abstract}

Keywords: multimedia learning materials, conceptual change, cognitive conflict strategy

\section{Introduction}

\subsection{Misconception in Learning}

Consistently, students often hold conceptions that are incompatible with established knowledge. These conceptions are often referred to as 'misconceptions'. Usually, those who are in this situation refuse to change their views on the subject in question. If the number of misconceptions increases, students will have difficulty in understanding the subject's material.

There are two implications of misconceptions in the teaching and learning process (Ulthayakumari, 2005). First, if misconceptions are not detected and corrected immediately, it can lead to an incorrect understanding of the concepts thus would the affect the students' achievement. The second implication is that students learn the knowledge in an abstract concept. In this situation, students may only memorise the concept due to lack of understanding. By simply memorising a concept is not good enough to give students a real understanding, and learning might become useless and meaningless. Misconceptions within the topic can be solved if detected earlier. A complete process starting from misconception to arrive at the replacement of correct information with the one in conflict can be described as conceptual change (Kabaca, Karadag, \& Aktumen, 2011). The condition of conceptual change is students have to feel dissatisfied with the conceptions they are presently taking. This 
occurs when students acknowledge the differences between new knowledge and their existing knowledge. Then, conceptual change will take place. In other words, they have to replace or upgrade their existing knowledge.

Majority of conceptual change researches take a cognitive perspective (Kabaca et al., 2011; Limo, 2001). Students feel some dissatisfaction towards current ideas. Therefore, the new ideas must appear plausible and intelligible (P. Hewson \& M. Hewson, 1984; Strike \& Posner, 1992). The focus key to success in cognitive conflict strategy is ensuring that the students construct or restructure a correct framework for their current knowledge by concerning teaching and learning approach (Arons, 1991; Lauren \& Leopold, 1989). The students do recognise the anomalous situation, experience strong interest and/or appropriate anxiety, and reappraise the cognitive conflict situation the right way. The final result of cognitive conflict is constructive. Cognitive conflict strategy helps improve students' performance by changing degrees of conflict regarding conservation problems (Bell, 1993; Niaz, 1995). Due to that, cognitive conflict strategy can be used to enhance conceptual change to reduce students' misconceptions. Based on this viewpoint, cognitive conflict strategy is highlighted as important in the conceptual change of students' learning.

\subsection{Cognitive Conflict in Multimedia Learning Environment}

Students' learning approaches might affect their cognitive conflict. This means that students accept the contradictory data and accommodate their existing knowledge, or they use some several coping tactics to avert the conflict. For instance, cognitive conflict can be used as a mechanism for supporting developmental progressions in students' knowledge about proof (A. Stylianides \& G. Stylianides, 2008). Besides that, students use a meaningful learning strategy when reacting to new difficulties by self-questioning and by relating and elaborating ideas, whereas their counterparts tend to react by stating definitions thus they fail to expand their minds (Donn, 1989). These techniques contribute to successful cognitive engagement. The effectiveness of cognitive conflict strategy in the learning procedure and understanding is not deniable because there is a great deal of research evidences that have been carried out in various subjects. For example, cooperative learning by using cognitive conflict strategy increases students' critical and creative thinking in Mathematics (Dahlan \& Rohayati, 2012). Cognitive conflict instruction improves students' understanding of Physics concepts more than traditional instruction (Baser, 2006). Students are more capable of noticing the inconsistencies between the discrepant events in Science and their existing conceptions by using this cognitive conflict strategy (Kang, Scharmann, \& Noh, 2004) .

Positive effects of multimedia learning tool are of significant help in the case of teaching generation $Y$ who have grown up with digital lifestyles. For creating a meaningful learning scenario, many researchers have shown that multimedia learning materials have a positive impact on the students in their cognitive performance (Goldman, 2004; Lin, 2010; White, Easton, \& Anderson, 2000), practical skills (Donkor, 2010), and motivation in learning (Choi \& Johnson, 2005). Due to that, cognitive conflict strategy embedded within multimedia learning tools gives a more meaningful result to the students. The multimedia learning materials are able to inspire students, persuade their attentiveness, and stimulate their motivation while providing information. Motivation and promotion may act as the main points in leading students through the conceptual change process (Schraw \& Lehman, 2001; Sinatra, 2005a). A courseware implemented with cognitive conflict strategy in a class has been claimed to offer a stress-free teaching and learning approach (Kabaca et al., 2011). Formerly, a simulation-assisted learning method based on the cognitive conflict theory seems to enhance a meaningful conflict (Nilsson \& Castro, 2013). Subsequently, a video demonstration may be used to create a cognitive conflict, resolution of which would lead to further understanding of the concept (Baddock \& Bucat, 2008). This means that the effectiveness of a combination of cognitive conflict strategy along with the worthwhile benefits of multimedia learning tools may lead to a more meaningful learning process for the students. Even so, which elements of cognitive conflict strategy that are usable within the multimedia learning tools are still an ongoing inquiry.

\section{Method}

This study aimed to identify the elements of cognitive conflict strategy for enhancing conceptual change in multimedia learning materials. The following key words were used to search for related publications: cognitive conflict strategies, conceptual change process, and multimedia learning material. A literature review was conducted via ScienceDirect, Web of Science, ProQuest, and IEEExplore Digital Library. The search produced 46 hits, but only 7 were deemed relevant to this study. These criteria were used in searching for the relevant literature: (1) the studies on cognitive conflict to assist the conceptual change process; (2) the studies must be published between 2001 until the present; and (3) the studies must mention what can be done in helping students' conceptual change process. The reason for only selecting studies published from 2001 until recently was to ensure that the research was current and up-to-date. After being analysed qualitatively, a meta-analysis of studies 
on cognitive conflict strategy for conceptual change was conducted, and the results are summarised in Table 1.

Table 1. Literatures on the elements of cognitive conflict strategy

\begin{tabular}{|c|c|c|c|}
\hline No. & $\begin{array}{l}\text { Element of Cognitive } \\
\text { Conflict Strategy }\end{array}$ & Description & Study \\
\hline \multirow{2}{*}{1} & \multirow{2}{*}{ Meaningful information } & $\begin{array}{l}\text { Learning materials should have high } \\
\text { efficacy for giving clear concept to } \\
\text { students. }\end{array}$ & $\begin{array}{l}\text { (Lee et al., 2003a; Baser, 2006; } \\
\text { Nilsson \& Castro, 2013) }\end{array}$ \\
\hline & & $\begin{array}{l}\text { Capability to introduce contradictory } \\
\text { information to induce cognitive } \\
\text { conflict. }\end{array}$ & $\begin{array}{l}\text { (Kang et al., 2004; Lee et al., } \\
\text { 2003b) }\end{array}$ \\
\hline \multirow[b]{2}{*}{2} & \multirow{2}{*}{$\begin{array}{l}\text { Challenging } \\
\text { existing concept }\end{array}$} & $\begin{array}{l}\text { Identify students' current state of } \\
\text { knowledge. }\end{array}$ & (Kang et al., 2004; Baser, 2006) \\
\hline & & $\begin{array}{l}\text { Focus on condition that promotes a } \\
\text { situation where the existing concept } \\
\text { can be explicit. }\end{array}$ & $\begin{array}{l}\text { (Baddock \& Bucat, 2008; Kabaca } \\
\text { et al., 2011; S. Kang et al., 2004) }\end{array}$ \\
\hline 3 & Ability to gain attention & $\begin{array}{l}\text { Provide situational interest by } \\
\text { identifying students' characteristics. }\end{array}$ & $\begin{array}{l}\text { (Baddock \& Bucat, 2008; H. Kang, } \\
\text { Scharmann, Kang, \& Noh, 2010; } \\
\text { Nilsson \& Castro, 2013) }\end{array}$ \\
\hline 4 & Motivation & $\begin{array}{l}\text { Provide situation that makes students } \\
\text { feel curious about the topic to } \\
\text { motivate learning process. }\end{array}$ & $\begin{array}{l}\text { (Kabaca et al., 2011; Lee et al., } \\
\text { 2003b) }\end{array}$ \\
\hline 5 & $\begin{array}{l}\text { Comfortability in using the } \\
\text { multimedia learning } \\
\text { materials }\end{array}$ & $\begin{array}{l}\text { Provide the ideas that are able to } \\
\text { bring cognitive conflict to become } \\
\text { lighter. }\end{array}$ & (Baddock \& Bucat, 2008) \\
\hline
\end{tabular}

Table 1 shows cross-disciplinary researches namely Science, Mathematics, Chemistry, and Economics. Still, a lot of these studies were implemented through face-to-face classroom instruction. The growth of multimedia resources may help students learn through cognitive conflict strategy for enhancing their conceptual change processes.

\section{Results}

Based on the meta-analysis, five elements of cognitive conflict strategy can be embedded within multimedia learning materials for a conceptual change process.

\subsection{Meaningful Information}

Cognitive conflict is the first place in the process of conceptual change. To guide the process of change, information must be meaningful for the person. The lack of concrete ideas might cause troubles when the cognitive conflict strategy has been carried out. Therefore, the strategy of presenting a typical data or conflicting information has been frequently chosen as the best way to induce cognitive conflict. The strategy is used to provoke conceptual change in an effort to make the students alert of the dissimilarities between their own beliefs, concepts or theories and the new information (Limo, 2001). By using a teaching and learning procedure like drawing analogies, metaphors, or a treatment with a partner or in group, it may lead to the cognitive conflict. So, this element will lead the students to undergo conceptual change and to help the students organise the conflict. Thus, the learning material should have meaningful information and high self-efficacy for giving clear concepts.

\subsection{Challenging Students' Existing Concept}

Many studies on conceptual change have focused on manufacturing conditions that promote situations where the students' existing conception can be made explicit before being immediately challenged to produce a land of conflict (Chan, Burtis, \& Bereiter, 1997). So, this strategy is a creative endeavour that needs students to have a deep insight into the relationships between the facts learned. Therefore, cognitive conflict strategy supports the conceptual change by defining learning as the interaction that takes place between students' experience and their current conceptions. 


\subsection{Ability to Gain Attention}

Students can achieve more when they allocate more attention to learning materials in order to determine a conceptual change (Limon, 2003). However, a positive influence of attention on learning is reflected not only by longer attention duration, but also by intensity and more cognitive effort (Ainley, Hidi, \& Berndorff, 2002). Hence, it has been shown that situational interest provokes conceptual change by some factors. For example, if students' characteristics are given due consideration, they would give full attention to the multimedia learning materials.

\subsection{Motivation}

Experiencing conflict is essential to learning. Besides that, the need to reduce conflict is a powerful human motivation. Therefore, a teacher must encourage students to stimulate their motivation by making the students feel curious in the learning activities, leading them to conceptual change (Sinatra, 2005b). To encourage meaningful cognitive conflict, students should be motivated and interested in the topic. Teachers should activate the students' prior knowledge. Certain epistemological beliefs and adequate reasoning abilities should also be applied (Limo, 2001).

\subsection{Comfortability in Using the Multimedia Learning Materials}

The execution of cognitive conflict in leading to conceptual change depends on the teacher. The teacher should act as a facilitator in the discussion along with the implications of conflicting ideas. The teacher must also demonstrate the ability to bring cognitive conflicts to light (Weaver, 1998). Therefore, the students would feel comfortable with the learning activities, and the conceptual change processes would be easier to take place.

\section{Suggestion for Future Research}

Cognitive conflict strategy is promising and has a bright future. This strategy has some advantages including correcting students' existing concepts, overcoming their misconceptions, and improving their performance. However, this strategy has been mostly applied in traditional setting, i.e., classroom instruction. Expectedly, the multimedia developer will thus develop multimedia learning materials and implement cognitive conflict strategy. Moreover, we suggest that elements of cognitive conflict strategy to be carefully embedded in multimedia tools in order to promote an effective conceptual change process.

\section{Conclusion}

In conclusion, the five elements of cognitive conflict strategy should be considered in developing multimedia learning materials in order to activate students' conceptual change process. The elements of cognitive conflict strategy for multimedia learning materials are as follows:

- Meaningful information;

- Challenging students' existing concept;

- $\quad$ Ability to attract attention;

- Motivation; and

- Comfortability in using the multimedia learning materials.

Optimistically, these elements will be used by educators to develop their multimedia learning materials. Whether all or just some of the elements should be applied within the multimedia learning materials, which then effectively promotes students' conceptual change, is still uncertain and must be further investigated.

\section{Acknowledgments}

The authors would like to thank Universiti Teknologi Malaysia (UTM) and Ministry of Education, Malaysia (MOE) for their support in making this project possible. This work was supported by the project under the Fundamental Research Grant (Vote No. R.J130000.7831.4F456).

\section{References}

Ainley, M., Hidi, S., \& Berndorff, D. (2002). Interest, learning, and the psychological processes that mediate their relationship. Journal of Educational Psychology, 94(3), 545-561. http://dx.doi.org/10.1037/0022-0663.94.3.545

Arons, A. B. (1991). A Guide to Introductory Physics Teaching. American Journal of Physics, 59(2), 189. http://dx.doi.org/10.1119/1.16610

Baddock, M., \& Bucat, R. (2008). Effectiveness of a Classroom Chemistry Demonstration using the Cognitive 
Conflict Strategy. International Journal of Science Education, 30(8), 1115-1128. http://dx.doi.org/10.1080/09500690701528824

Baser, M. (2006). Fostering Conceptual Change by Cognitive Conflict Based Instruction on Students' Understanding of Heat and Temperature Concepts. Eurasia Journal of Mathematics, Science and Technology Education, 2(2).

Bell, A. (1993). Some experiments in diagnostic teaching. Educational Studies in Mathematics, 24, 115-137.

Chan, C., Burtis, J., \& Bereiter, C. (1997). Knowledge Building as a Mediator of Conflict in Conceptual Change. Cognition and Instruction, 15(1), 1-40. http://dx.doi.org/10.1207/s1532690xci1501_1

Choi, H. J., \& Johnson, S. D. (2005). The Effect of Context-Based Video Instruction on Learning and Motivation in Online Courses. American Journal of Distance Education, 19(4), 215-227.

Dahlan, J. A., \& Rohayati, A. (2012). Implementasi strategi pembelajaran konflik kognitif dalam upaya meningkatkan Hihg Order Mathematical Thinking Siswa. Jurnal Pendidikan, 13(2), 65-76.

Donkor, F. (2010). The Comparative Instructional Effectiveness of Print-Based and Video-Based Instructional Materials for Teaching Practical Skills at a Distance. International Review of Research in Open and Distance Learning, 11(1), 96-115.

Donn, S. (1989). Epistemological issues in science education. San Francisco, CA.

Goldman, R. (2004). Video perspectivity meets wild and crazy teens: A design ethnography. Cambridge Journal of Education, 34(2), 157-178.

Hewson, P., \& Hewson, M. (1984). The role of conceptual conflict in conceptual change and the design of science instruction. Instructional Science, 13(1), 1-13.

Kabaca, T., Karadag, Z., \& Aktumen, M. (2011). Misconception , cognitive conflict and conceptual changes in geometry: A case study with pre-service teachers. Mevlana International Journal of Education (MIJE), 1(2), 44-55.

Kang, H., Scharmann, L. C., Kang, S., \& Noh, T. (2010). Cognitive conflict and situational interest as factors influencing conceptual change. International Journal of Environmental and Science Education, 5(4), 383-405.

Kang, S., Scharmann, L. C., \& Noh, T. (2004). Reexamining the Role of Cognitive Conflict in Science Concept Learning. Research in Science Education, 34(1), 71-96.

Lauren, B., \& Leopold, E. (1989). Toward the Thinking Curriculum: Current CognitiveResearch (p. 232).

Lee, G., Kwon, J., Park, S.-S., Kim, J., Kwon, H., \& Park, H. (2003a). Development of an instrument for measuring cognitive conflict in secondary-level science classes. Journal of Research in Science Teaching, 40(6), 585-603. doi:10.1002/tea.10099

Lee, G., Kwon, J., Park, S.-S., Kim, J., Kwon, H., \& Park, H. (2003b). Development of an instrument for measuring cognitive conflict in secondary-level science classes. Journal of Research in Science Teaching, 40(6), 585-603. doi:10.1002/tea.10099

Limo, M. (2001). On the cognitive conflict as an instructional strategy for conceptual change: A critical appraisal. Learning and Instruction, 11(4-5), 357-380.

Limon, M. (2003). The role of domain-specific knowledge in intentional conceptual change. In G. M. Sinatra, \& P. R. Pintrich (Eds.), Intentional conceptual change (pp. 133-170). Mahwah, NJ: Erlbaum.: Taylor \& Francis Ltd.

Lin, L.-F. (2010). Video-Based CALL Program for Proficient and Less-Proficient L2 Learners' Comprehension Ability, Incidental Vocabulary Acquisition. Educational Media International, 47(3), 199-216. http://dx.doi.org/10.1080/09523987.2010.518812

Niaz, M. (1995). Cognitive conflict as a teaching strategy in solving chemistry problems: a dialectic contructivist perpective. Journal of Research in Science Teaching, 32(9), 959-970.

Nilsson, W., \& Castro, B. (2013). Simulation Assisted Learning in Statistics: How important are students' characteristics? (p. 23). Retrieved from http://econpapers.repec.org/paper/ubideawps/56.htm

Schraw, G., \& Lehman, S. (2001). Situational Interest: A Review of the Literature and Directions for Future Research. Educational Psychology Review, 13(1), 23-52. 
Sinatra, G. M. (2005a). The "Warming Trend" in Conceptual Change Research: The Legacy of Paul R. Pintrich. Educational Psychologist, 40(2), 107-115. http://dx.doi.org/10.1207/s15326985ep4002_5

Sinatra, G. M. (2005b). The "Warming Trend" in Conceptual Change Research: The Legacy of Paul R. Pintrich. Educational Psychologist, 40(2), 107-115. http://dx.doi.org/10.1207/s15326985ep4002_5

Strike, K., \& Posner, G. (1992). Are visionist theory of conceptual change. In Philosophy of science, cognitive psychology, and educational theory and (pp. 147-176). Albany: State University of New York Press.

Stylianides, A. J., \& Stylianides, G. J. (2008). "Cognitive Conflict" as a Mechanism for Supporting Developmental Progressions in Students' Knowledge about Proof. In 11th International Congress on Mathematical Education (pp. 1-11). Retrieved from http://tsg.icme11.org/tsg/show/19

Ulthayakumari. (2005). Penguasaan dan Penyelesaian Masalah di Kalangan Pelajar Tingkatan Empat (4) di Daerah Kluang. Universiti Teknologi Malaysia, Skudai.

Weaver, G. C. (1998). Strategies in K-12 science instruction to promote conceptual change. Science Education, 82(4), 455-472.

White, C., Easton, P., \& Anderson, C. (2000). Students' Perceived Value of Video in a Multimedia Language Course. Educational Media International, 37(3), 167-175. http://dx.doi.org/10.1080/09523980050184736

\section{Copyrights}

Copyright for this article is retained by the author(s), with first publication rights granted to the journal.

This is an open-access article distributed under the terms and conditions of the Creative Commons Attribution license (http://creativecommons.org/licenses/by/3.0/). 